\title{
Orundellico-Jemmy Button: o(s) lugar(es) e a(s) identidade(s)
}

Guillermo Giucci

A oposição entre "dentro" e "fora" que por muitos anos configurou nossa imagem de espaço, é hoje confrontada com novos desafios territoriais. Enquanto uma vertente da reflexão contemporânea sobre o espaço destaca a importância de perspectivas alternativas - "heterotopias", "entre lugar", "espaço fronteiriço", "não lugar", "espaço virtual" -, outra, assinala o desaparecimento do sentido de exterioridade. O escritor Mario Vargas Llosa uma vez definiu a literatura como uma forma de luta contra o perigo das fronteiras artificiais:

Sim, sou peruano, sou latino americano, porém vivi, também, tantos anos no exterior que já sou um pouco de todos os países em que vivi. Acredito que minha pátria é o mundo; sou cidadão do mundo desde cedo e não lamento, pelo contrário. Uma das boas coisas que aconteceram comigo foi poder me sentir em casa em vários lugares tão diferentes. Acredito que isso nos dá uma perspectiva, uma visão mais ampla da vida, das coisas, das pessoas. É uma vacina contra a visão provinciana, pequena, e também contra o nacionalismo, que é um dos grandes perigos, uma das principais fontes da falta de comunicação e dos preconceitos sociais, culturais e raciais. Ser desenraizado, de certa forma, é estar enraizado em uma coisa mais ampla, mais geral.

A figura exemplar deste apego ao espaço local é literária e é, por si só, uma expressão da mobilidade: o regresso de Ulisses a Ítaca, na Odisseia de Homero. A partida e o retorno sob a forma de círculo que se impóe de modo épico e violento, mas que expressa o triunfo da reconciliação entre a identidade e o lugar. Ao narrar suas desventuras a Alcino, Ulisses conta que não houve deusa que conseguisse detê-lo em nenhuma gruta ou palácio, pois "não há nada mais doce que a pátria e os pais, mesmo que se viva em casa luxuosa, mas distante, em um país estranho, deles separado" (Rapsódia IX). E quando o adivinho Tiresias lhe revela seu futuro, anuncia que sua morte dar-se-á longe do mar, quando, já tendo vivido uma prazerosa velhice, encontrar-se-á rodeado por cidadãos felizes (Rapsódia XI). Embora a literatura moderna siga narrando o vínculo entre o regresso e a casa, esta ideia se torna cada vez mais complexa em virtude da evolução das tecnologias de transporte e de comunicação, bem como da tendência, na modernidade tardia, ao lugar transnacional.

Sabemos que os regressos nunca são perfeitamente circulares. Não é necessário mencionar casos extremos como o do retorno do impostor Arnaud du Tilh que, no século XVI, assumiu a identidade do camponês do Languedoc, Martin Guerre - que, por sua vez, havia abandonado a família -, e desfrutou anos de agradável convivência com a esposa de Guerre, até que esta denunciou-o como impostor e o levou a julgamento. No último momento, quando Arnaud du Tilh quase havia convencido o júri de que era Martin Guerre, o verdadeiro se apresentou e o impostor foi condenado à morte. ${ }^{2}$ Também pertencem a uma categoria particular os regressos traumáticos de veteranos de guerra, ou de exilados políticos.

Contudo, mesmo que nos concentremos em exemplos menos traumáticos, encontramos retornos sobretudo os de caráter definitivo - carregados de ambivalências, dúvidas e conflitos, uma vez que manifestam o desejo de pertencimento a um único lugar no mundo, em um momento histórico em que a singularidade aparece como um projeto impossível. "Voltar não tem sentido / tampouco viver lá", diz a letra da canção "Los Olímpicos" do compositor e cantor uruguaio Jaime Roos. ${ }^{3}$ Ainda que a percepção da distância - do próximo e do distante - tenha mudado e ainda que, no contexto de comunicação mundial, a partida e o retorno já não signifiquem o mesmo que em tempos passados, os lugares físicos ainda são geradores de fortes ressonâncias emocionais especialmente aqueles percebidos como "maternais", marcados pela família, pelo monolinguismo, pela adolescência e pela pátria. Em contrapartida, o imigrante judeu e escritor tcheco naturalizado brasileiro Vilém Flusser, ${ }^{4}$ questionou o essencialismo da noção de 
pátria, argumentando que se poderia mudar de pátria, mas que sempre se teria que viver em algum lugar. Neste trabalho proponho discutir a relação entre o lugar e a identidade tomando como base a figura histórica do índio yamana Orundellico, mais conhecido pelo nome de Jemmy Button. Lamentavelmente, não há nenhum relato direto do próprio Orundellico-Jemmy Button; apenas narrativas indiretas.

\section{A captura filantrópica}

Entre 1826 e 1836 foram realizadas duas importantes expedições inglesas de estudos hidrográficos na região mais meridional do continente americano. Era de vital importância para o Almirantado desbravar essas costas desoladas e longínquas e as vias marítimas, pois convinha contar com um porto de abastecimento para os navios, em suas viagens de ida e volta à rede de colônias inglesas espalhadas pelo mundo. Temos muitas informações sobre essas duas expedições, graças à publicação, em 1839, de Narrative of the Surveying Voyages of His Majesty's Ships Adventure and Beagle between the Years 1826 and 1836, describing their Examination of the southern Shores of South America, and the Beagle's Circumnavigation of the Globe. Trata-se de uma publicação em três volumes, organizada pelo comandante Robert FitzRoy: o primeiro, de autoria do comandante Phillip Parker King; o segundo volume e um apêndice, escritos pelo comandante FitzRoy; e o terceiro volume, cujo subtítulo é Journal and Remarks 18321836, de autoria de Charles Darwin.

Os dois primeiros volumes eram ilustrados e incluíam apêndices, diferentemente do terceiro. Contudo, foi justamente este que, rapidamente, alcançou maior destaque, a ponto de o texto de Charles Darwin passar a ser publicado separadamente, com o título Journal of Researches into the Geology and Natural History of the Countries visited during the Voyage of H. M. S. Beagle round the World, under the Command of Capt. FitzRoy, R. N. O sucesso de seu primeiro livro sempre deu muito orgulho a Darwin que, em 1845, revisou cuidadosamente o texto, desde então publicado com ilustraçôes e com o título ligeiramente alterado em relação à ordem das palavras. Essa edição definitiva de 1845 é a que hoje se conhece mundialmente sob o título The Voyage of the Beagle.

A primeira expedição, de maio de 1826 a outubro de 1830, contou com os veleiros Adventure e Beagle, conduzidos, respectivamente, pelos comandantes King e Pringle Stokes. Sua missão consistia em explorar as costas meridionais da América do Sul, uma zona muito vasta que se estendia do Cabo San Antonio no Oceano Atlântico à Ilha de Chiloé no Pacífico.

Com a intenção de investigar cuidadosamente a parte do sul do Estreito de Magalhães, a menos conhecida pelos europeus, estabeleceu-se um quartel general em Puerto Hambre e a pequena frota separou-se. O Beagle dirigiu-se à entrada ocidental do Estreito, com ordens de retornar ao quartel general ao final de março, enquanto o bote Hope, foi enviado com sete marinheiros a bordo para explorar o Canal San Sebastián.

O uso do Hope, no lugar do veleiro Adventure, indica a importância das pequenas embarcações na exploração do arquipélago ao largo da Terra do Fogo. Os botes passam a ser indispensáveis devido à sua capacidade de manobra, isto é, à facilidade com que entravam e saíam de pequenas enseadas e de portos naturais. Sobre os aborígenes da região próxima à ilha Dawson, que surgem seminus, com o corpo pintado e coberto com óleo de foca, chama a atenção dos marinheiros o cheiro forte, quase intolerável, de seus corpos e o extremo valor que davam a contas e botôes; por essas bugigangas, os nativos venderiam "a canoa, a esposa, os filhos, seus cães e toda a mobília". 5

Veremos mais adiante, com o exemplo de Jemmy Button, o complexo desenvolvimento ideológico de tais comentários. O que indiscutível, entretanto, é o estabelecimento de redes comerciais entre os europeus e os nativos fueguinos. ${ }^{6}$ Desde o primeiro contato entre os espanhóis e os índios Alakaluf, em 1526, inicia-se um comércio regular que, três séculos depois, incluía não só contas e botões, mas, carne de guanaco, couro, cães, álcool, facas, ferramentas e armas, além do uso do cavalo mais ao norte, e da caça de baleias, focas e pinguins na região do Cabo Horn. 
Em março de 1828, o Adventure (acompanhado pela escuna Adelaide) e o Beagle estão novamente em Puerto Hambre, prontos para continuar sua missão. No entanto, desta vez, terão que enfrentar problemas inesperados. Aparece o escorbuto que não pode ser controlado devido à falta de alimentos frescos e que contribui para um ambiente de prostração geral, agravada pela morte acidental de alguns marinheiros. Para complicar ainda mais a situação, o comandante Stokes, doente, deprimido e envergonhado por sua imperícia técnica, tranca-se em sua cabine, suicidando-se com um tiro na cabeça, vindo a falecer após onze dias de delírio e agonia. Seu corpo está enterrado no Cemitério Inglês de Puerto Hambre. Uma inscrição na cruz de sua lápide lembra sua passagem pelo fim do mundo: "Em memória do comandante Pringle Strokes R. N. / H. M. S. Beagle / Morto pelos efeitos de angústias e dificuldades, durante a exploração das costas ocidentais da Terra do Fogo. 12-8-1828"7 (a cruz original encontra-se no Museu Salesiano em Punta Arenas, Chile).

Montevidéu e Rio de Janeiro foram, mais uma vez, os portos de reparo para o Adventure e o Beagle. Uma vez que a tarefa de exploração das costas meridionais não estava concluída, seria lógico que o tenente Skyring fosse nomeado comandante da próxima viagem do Beagle ao extremo sul. Entretanto, o comandante-em-chefe da frota da América do Sul, Robert Otway, decidiu nomear o promissor tenente e aristocrata Robert FitzRoy, então com 23 anos e oficial de serviço no veleiro Ganges, fundeado no porto do Rio de Janeiro. FitzRoy assumiu o comando do Beagle, em 15 de dezembro de 1828, ávido para provar sua capacidade e coragem na ameaçadora região fueguina a qual desconhecia completamente.

Causa espanto a juventude desses indivíduos, obrigados repentinamente a assumir o comando de expediçōes científicas em regiōes apenas parcialmente exploradas. Fragmentos do diário de FitzRoy, incluídos no primeiro volume, nos dão uma ideia bastante precisa da psicologia do novo comandante do Beagle, quando, em 13 de abril de 1829, depara-se com os "primeiros selvagens" nos arredores do Cabo Negro, nos quais efetua um rápido exame de frenologia. ${ }^{8}$ FitzRoy refere-se, nesta ocasião, a fueguinos muito sujos com fisionomias que indicavam malícia, indolência, força passiva, deficiência intelectual e falta de energia.?

Em princípios de fevereiro de 1830, o comandante FitzRoy foi informado que um bote baleeiro havia sido roubado pelos nativos nas imediações da Península Brecknock, região ocidental da Terra do Fogo. O Beagle estava ancorado em uma enseada na Ilha London, enquanto os marinheiros inspecionavam os arredores com os botes disponíveis. Uma pequena tripulação explorava a área conhecida como Cabo da Desolação, quando uma tempestade obrigou o grupo a refugiar-se em uma pequena enseada, ficando o bote amarrado na praia. Naquela mesma noite, ele desapareceu. Diante do roubo não restou outra alternativa senão construir uma embarcação precária - semelhante a uma cesta (basket) - para que dois marinheiros pudessem ir até o Beagle informar o ocorrido ao comandante. O bote roubado era justamente o construído, poucos meses antes, pelo carpinteiro May na Ilha de Chiloé, e que FitzRoy considerava excelente e de vital importância para a exploração da região fueguina.

O comandante mobilizou-se imediatamente para tentar recuperar o barco. Mas seus esforços foram em vão, apesar dos inúmeros deslocamentos, das ameaças e dos ataques. Frustrado com a perda e convencido de que o bom tratamento dispensado aos nativos era inútil - com os selvagens funcionava unicamente o medo ao castigo -, FitzRoy começou a sequestrar fueguinos, como moeda de troca: índios pelo barco. Dos dois homens, três mulheres e seis crianças capturados em uma emboscada, após sucessivas fugas, sobrou apenas a menina Fuegia Basket, assim chamada pelos ingleses em alusão à forma da precária canoa que havia sido utilizada para informar sobre o roubo do bote baleeiro.

Dias depois, aumentou o grupo de índios cativos: York Minster foi capturado na área do promontório York Minster (nome dado por Cook a um promontório fueguino a partir de uma suposta analogia com a catedral gótica de mesmo nome, no Condado de York, Inglaterra, uma das maiores do norte da Europa $)^{10}$ e, mais tarde, Boat Memory, assim chamado em alusão ao bote perdido. Deslocamo-nos "naturalmente" da inspeção geográfica para a história dos cativos, embora seja indubitável que o apre- 
samento de fueguinos não fazia parte das instruções originais do Almirantado, razão pela qual FitzRoy deverá explicar suas ações.

A captura de índios americanos não era uma novidade. Desde Cristóvão Colombo tornara-se um hábito dos europeus transportar indígenas, negócio no qual participavam espanhóis, portugueses, holandeses e franceses. O que chama a atenção no caso de FitzRoy é o peso na consciência e o cuidado para com os cativos. Apesar disso, entende-se melhor a captura de aborígenes fueguinos como parte de uma ampla coleção "natural" que incluía de plantas e animais a seres humanos.

Embora a Terra do Fogo oferecesse poucos atrativos e FitzRoy considerasse-a inadequada para o uso do homem civilizado, ele estava convencido da necessidade do aprendizado mútuo das línguas para empregar informantes locais, descobrir a possível existência de minerais e educar os selvagens. $\mathrm{O}$ comandante ofereceu uma resumida descrição dos três Alakaluf sequestrados:

Boat Memory era o fueguino mais bem apessoado que eu já havia visto; jovem e bem feito, era um promissor espécime da raça. York Minster, pelo que pude observar, era, entre eles, um dos homens mais robustos; mas, a pequena Fuegia Basket tinha, de largura, quase tanto quanto de altura e parecia tão alegre e feliz que não acho que ela estaria disposta a nos deixar. Penso que não poderíamos ter encontrado três nativos da Terra do Fogo mais apropriados para serem instruídos e para dar, assim como para receber, informações. ${ }^{11}$

Mais tarde, em 30 de maio de 1830, juntar-se-ia ao trio de sequestrados Jemmy Button, cujo nome deve-se ao fato de este índio ter sido supostamente vendido por seus familiares em troca de um botão nacarado, na região do canal Murray (nela, existe atualmente a ilha Jemmy Button). Como ele não pertencia ao grupo Alakaluf, mas, ao Yamana, falava um dialeto diferente e não podia comunicar-se com ninguém. O relato de FitzRoy diminui o caráter dramático do fato de um menino ser separado de sua família, tornando-o quase banal:

Demos a eles contas e botôes em troca de alguns peixes e, sem haver premeditado, convidei um dos meninos em uma canoa para vir ao nosso barco e dei ao homem que estava com ele um grande e brilhante botão de madre-pérola. $\mathrm{O}$ menino entrou imediatamente no barco e se sentou. Vendo que tanto ele quanto seus amigos pareciam bastante contentes, puxei o barco à frente que, impelido por uma leve brisa, começou a navegar. Achando que esta ocorrência acidental pudesse ser útil para os nativos, assim como para nós mesmos, resolvi tirar vantagem dela. (...) "Jemmy Button", como a tripulação do barco o chamava em alusão ao objeto pelo qual havia sido trocado, parecia satisfeito com a mudança e imaginava que ia caçar guanacos ou wãnãkãye, como os denominavam -, uma vez que podiam ser encontrados perto daquele lugar. ${ }^{12}$

Dias depois, FitzRoy volta a justificar o transporte dos fueguinos usando o argumento dos benefícios da civilização:

Eu havia previamente decidido levar à Inglaterra os fueguinos que tínhamos conosco, confiando que os benefícios decorrentes do conhecimento de nossos hábitos e língua iriam compensá-los da separação temporária de sua própria terra. Contudo, esta decisão não havia sido tomada quando eu os trouxe a bordo; pensava, apenas, em mantê-los conosco enquanto estivéssemos navegando pela costa. Posteriormente, percebendo que estavam felizes e que gozavam de boa saúde, comecei a pensar nas muitas vantagens que poderiam resultar para eles e seus conterrâneos, bem como para nós, em levá-los para a Inglaterra, educá-los tanto quanto fosse possível e depois trazê-los de volta à Terra do Fogo. ${ }^{13}$

Durante a lenta travessia até a Inglaterra, o comandante aproveitou o tempo disponível para se comunicar com os cativos. Inteira-se da prática do canibalismo, indignidade que aparece em um relato, não se tratando de uma experiência pessoal. Mas, já neste período de convivência forçada no barco, três deles - Fuegia Basket, Boat Memory e Jemmy Button - foram perdendo, para o comandante do Beagle, a conotação de selvagens. Este processo de humanização ou, em outras palavras, de adaptação progressiva ao modelo do paternalismo inglês, enfrentava um inimigo declarado na resistência passiva de York Minster aos costumes civilizados; esse índio, consequentemente, revelava-se como um exemplo 
desagradável da natureza humana em seu estado selvagem. Era compreensível essa resistência de York Minster, pois ele completara 26 anos e era o mais velho do grupo. Havia sido capturado em Christmas Sound e servido como intérprete e guia, sendo obrigado posteriormente a uma travessia pelos mares. Boat Memory tinha 20 anos; Jemmy (também chamado James) Button, entre 12 e 14; a menina Fuegia Basket, uns 9 anos.

Tudo indica que FitzRoy ocupou-se pessoalmente do bem estar dos fueguinos a quem chamava de seus "protegidos". Arcou com seus gastos e prometeu-lhes que se tratava de uma viagem de ida e volta, portanto que regressariam à sua terra. É uma promessa que pesará na consciência do comandante, a ponto de se dispor a gastar parte de sua fortuna para levá-la a cabo.

Os fueguinos cativos iniciaram a travessia de regresso à Terra do Fogo em 27 de dezembro de 1831. Fazia tempo que seus nomes eram outros - yok'cushlu havia se convertido em Fuegia Basket; el'leparu, em York Minster; órundel'lico, em Jemmy Button. Também havia sido criado um dicionário básico das línguas Alakaluf e Yamana. Além disso, FitzRoy, seguidor da emergente ciência da frenologia difundida por Johann Gaspar Spurzheim e George Combe, e o médico John Wilson tinham realizado uma série de exames com o objetivo de observar as inclinações, os sentimentos e os órgãos intelectuais dos fueguinos. A frenologia atingira o seu auge na poderosa e expansionista Inglaterra, fundindo-se com as teorias da superioridade da raça dominante. Justamente em Londres, em 1830, os cativos fueguinos foram submetidos a observações de frenologia: Yokcushlu [Fuegia Basket], uma menina de dez anos com um sentimento forte por um Ser Supremo, poderia ser transformada, em breve, em uma pessoa útil para a sociedade, pois aceitava com facilidade a educação (inglesa). Orundellico [Jemmy Button], de 15 anos, benevolente, mas não muito inteligente, gostava de liderar, porém devia lutar contra suas inclinações animalescas. El'leparu [York Minster], com aproximadamente 28 anos, era muito apaixonado e determinado, generoso com aqueles que o ajudavam, mas reservado em demonstrá-lo, difícil de ser instruído.

\section{Colecionar, catalogar}

Explorar a região da Terra do Fogo foi uma das tarefas centrais da segunda expedição inglesa à região meridional do continente americano, entre dezembro de 1831 e outubro de 1836 . Comandada por FitzRoy e realizada no já conhecido, ainda que reformado, veleiro Beagle, contava com excelentes instrumentos de medição, fundamentais para as observações barométricas, náuticas e cronométricas, além de uma carta do presidente da República do Chile, Joaquin Pietro, solicitando todo o apoio possível ao navio de Sua Majestade Britânica por tratar-se de um empreendimento proveitoso para a navegação, para o comércio e para a ciência.

Embora dessem continuidade, sobretudo, aos estudos hidrográficos, os ingleses, desta vez, detiveram-se na dimensão religiosa e no conhecimento científico da terra. Entre os 74 tripulantes estava o catequista Richard Matthews, representante da Church Missionary Society e o único voluntário que aceitara embarcar para aprender o idioma dos fueguinos e ensinar-lhes os fundamentos da religião cristã. Seguramente não tinha mais do que 25 anos; por esta razão consideravam-no demasiado jovem para a tarefa assumida, embora reconhecessem sua dedicação. Desembarcado em Wulaia, na região habitada pelos índios yamana e acompanhado por Jemmy Button, pouco tempo depois abandonaria o projeto evangelizador, temendo por sua vida, sem alcançar nenhum resultado positivo. Se bem que possamos definir esse experimento religioso como um fracasso, a chegada de um catequista significa uma nova relação com o fim do mundo que prenuncia a importância das missões anglicanas e salesianas no processo de colonização da Terra do Fogo.

Durante a primeira expedição, FitzRoy havia lamentado a ausência de uma pessoa com conhecimentos em geologia para examinar a natureza das rochas. Esta foi uma das funçôes delegadas ao jovem naturalista inglês de 22 anos, Charles Darwin, nessa segunda expedição. A navegação ao redor do pla- 
neta proporcionou a Darwin um fascinante laboratório de pesquisa, conforme revelou em sua autobiografia: "a viagem do Beagle foi, de longe, o evento mais importante de minha vida, determinante para toda a minha carreira". ${ }^{14} \mathrm{O}$ livro The Voyage of the Beagle, mistura de diário pessoal e documento científico, foi um dos resultados dessa expedição de cinco anos ao redor do mundo.

O Beagle converteu-se em uma heteróclita Arca de Noé. As pesquisas, coleções e desenhos de Darwin nos mostram o entusiasmo deste jovem naturalista que nunca se recuperaria de uma doença possivelmente contraída na América do Sul. De onde fosse possível, Darwin enviava desde sementes e folhas a esqueletos de animais para o professor Henslow, em Cambridge. Diferentemente de seus companheiros, que se detinham nos estudos hidrográficos, Darwin permanecia longos períodos em terra. De fato, uma das condições para participar da expedição era que pudesse deixar o barco quando considerasse conveniente. Como o Beagle permaneceu a maior parte do tempo na área onde convergem os oceanos Pacífico e Atlântico, Darwin coletou, com a ajuda do adolescente Syms Covington, uma notável quantidade de exemplares da flora e da fauna sul-americanas. Isto explica, em parte, a singularidade e o êxito de seu livro.

$\mathrm{O}$ ato de coletar e a ciência aparecem intimamente associados no século XIX, de forma muito diferente da que ocorria no século XVI, quando muitos objetos e amostras constituíam-se em fonte de mera curiosidade pelo exótico. Sintomaticamente, na primeira edição, de 1839, de seu Narrative of the Surveying Voyages..., Darwin dedica algumas páginas, intituladas Advice to Collectors, aos métodos de colecionar; elas serão eliminadas nas edições posteriores. Apoiado em sua experiência de cinco anos, como colecionador viajando ao redor do mundo, afirma que convém seguir dois lemas: "Nunca confiar na memória" e "É melhor enviar para casa poucas coisas bem preservadas do que um grande número em más condições". ${ }^{15}$

Nesse "conselho" há recomendaçōes e advertências. É o cientista viajante quem exorta o colecionador para que faça registros exatos das datas do envio de pacotes e cartas à Inglaterra; a pessoa que os recebe também deverá fazer o mesmo. Cada espécie, ou fragmento de espécie, deve ter um número e a informação deve ser incluída imediatamente no catálogo, especificando-se sua localização geográfica. É melhor não ter muitos catálogos, mas, pelo menos dois (Darwin tinha um terceiro catálogo exclusivamente para espécimes geológicos e fósseis). Recomenda o uso de recipientes de vidro hermeticamente fechados; com isso evitam-se vazamentos e a evaporação. Adverte que, para as peles convém usar sabão arsênico e que não se deve esquecer de escovar as patas e o bico [dos espécimes coletados] com uma solução corrosiva. Se o colecionador, no estrangeiro, trabalhar arduamente de manhã à noite, sem dúvida será recompensado no futuro. Estamos diante de um processo de explicação e detalhamento que em breve produzirá - mais do que uma recompensa autoral - uma revolução no conhecimento científico: a teoria da evolução das espécies.

A Grã Bretanha destaca-se como a maior potência militar e científica da época e se expande pelo mundo. De diferentes regiōes do planeta chegam à Europa produtos estranhos que se tornam familiares, enquanto a Inglaterra e a França transformam-se em uma síntese do globo, como atestam as chamadas "Exposições Universais". Jacques Brosse assinala que, de todas as regiōes percorridas, "deveria ser extraído o maior número possível de informaçōes sobre física, hidrografia, navegação; sobre a flora e a fauna e, muito especialmente, sobre os povos que habitavam aquelas terras longínquas". ${ }^{16}$

Não por acaso a imagem do mundo à disposição do viajante europeu, constitui-se em estímulo ao deslocamento imperial; imagem do mundo sob uma dupla perspectiva: em mapas e como espaço disponível para a pilhagem e o comércio. O globo é um armazém colonial de matérias-primas e de objetos colecionáveis, assim como um vasto espaço potencial para o escoamento de produtos manufaturados e industrializados. A presença de navios, cientistas e comerciantes europeus em regióes "remotas" é uma confirmação de que as interaçôes econômicas e sociais operam em um nível global, como anteciparam Adam Smith, em A riqueza das naçôes (1776); Hegel, em seu curso de 1830 sobre Filosofia da História e Marx e Engels no Manifesto Comunista de 1848. 


\section{Comparar: os selvagens abjetos}

As viagens são um estímulo para as comparações. Ao chegar à Baía de Buen Suceso, na Terra do Fogo, em meados de dezembro de 1832, o missionário Richard Matthews reagiu com calma diante da visão dos primeiros selvagens que conhecia na sua vida, alegando que não eram piores do que havia imaginado. Contudo, convinha educá-los, assinalou outro tripulante, o Sr. Hamond, ao lamentar que pessoas que gozavam de tão boa saúde fossem abandonadas em tal estado de barbárie. O comandante FitzRoy estava totalmente de acordo com tal afirmação, tendo em vista que, agora, pretendia devolver três fueguinos à sua terra natal para, com isso, exibir os benefícios da civilização. As comparações já não se limitam à oposição civilização-barbárie, nem sequer à confrontação entre os próprios grupos fueguinos, mas, passam a considerar o estado selvagem dos nativos em relação ao dos cativos transculturados: o antes e o depois da viagem à Inglaterra de Jemmy Button, York Minster e Fuegia Basket. A aparência dos Tekeenica, habitantes do sudeste da Terra do Fogo, por exemplo, era, de acordo com FitzRoy, extremamente desagradável para as pessoas civilizadas, principalmente porque eram indivíduos de baixa estatura, corpo desproporcional, cabelo negro sujo e áspero, o que acentuava uma expressão indigna. Nos cativos, ao contrário, a forma da boca refinara-se, graças aos novos hábitos e à educação europeia, conforme as palavras do voluntarioso comandante.

Uma diferença fundamental entre os ingleses e os fueguinos era a prática do canibalismo que, no caso dos Yamana, havia sido descrita pela primeira vez pela expedição holandesa de Schapeham em 1623. FitzRoy dedica numerosas páginas ao canibalismo, que considera fato comprovado, ainda que se trate sempre de relatos, nunca de experiências pessoais. O testemunho dos cativos confirma que os fueguinos comiam carne humana em ocasiōes particulares, como em casos de vingança, ou de escassez generalizada de alimentos. $\mathrm{O}$ comandante especifica, inclusive, a divisão gastronômica: as mulheres comiam os braços e o peito; os homens devoravam as pernas; o torso era lançado ao mar. Em épocas de muita fome nem as mulheres mais velhas se salvavam: eram perseguidas, asfixiadas com fumaça, esquartejadas e comidas. Quem confirma ao comandante a veracidade de tais relatos é um menino de onze anos da tribo Chonos que serve de guia aos ingleses e diz ter presenciado tais sacrifícios.

Comparando a primeira edição de 1839 e a publicação definitiva de 1845 do livro de Charles Darwin, é possível perceber várias mudanças, sobretudo exclusōes e acréscimos. No texto de 1839, por exemplo, há unicamente uma rápida referência ao canibalismo entre os fueguinos - "não estão livres da fome e, por consequência, do canibalismo acompanhado de parricídio" ${ }^{17}$ - que será ampliada na edição de 1845 e se converterá em um dos episódios mais polêmicos do livro. Por outro lado, na publicação de 1845, Darwin acrescenta informaçôes sobre a história dos cativos fueguinos e de seu regresso à pátria que havia registrado em seu diário de viagem, mas, excluído da edição de 1839, quando, simplesmente, remete o leitor à narrativa de FitzRoy: "o comandante FitzRoy relatou todos os eventos interessantes que lá aconteceram". ${ }^{18}$ Sintomaticamente, no índice de 1839, não aparece o nome de Jemmy Button, incluído posteriormente.

O relato de Darwin está repleto de comparações, especialmente entre animais e cenários naturais. Mas, o método comparativo alcança sua maior intensidade quando compara raças humanas:

Entre os temas que dizem respeito ao indivíduo, talvez nada cause mais espanto do que ver, pela primeira vez, no covil natural de um bárbaro, o homem em seu estado mais baixo e mais selvagem. A mente volta, rapidamente, aos séculos passados e indaga: nossos ancestrais poderiam ter sido como esses homens? Homens, cujos traços e expressões são, para nós, menos inteligíveis do que os dos animais domésticos; homens que não possuem os instintos desses animais, nem que pareçam orgulhar-se da razão humana e, muito menos, das habilidades que derivam dessa razão. Eu, de fato, não acredito que seja possível descrever ou ilustrar a diferença entre selvagens e homens civilizados. ${ }^{19}$

O jovem naturalista tinha avistado os selvagens, pela primeira vez em sua vida, quando o Beagle entrou na Baía de Buen Suceso, em 17 de dezembro de 1832. Tudo prenunciava algo muito diferente 
do conhecido. A aventura e a revelação do fim do mundo ainda estão unidas quando Darwin registra em seu diário o prazer que sentiu ao ancorar em uma região tão agreste como a Terra do Fogo, onde o nome "Baía de Buen Suceso" evocava a ideia de descobrimento, sobretudo porque essa costa havia sido o primeiro lugar em que o comandante Cook havia fundeado, no século XVIII. ${ }^{20}$ Quem chega, sessenta anos depois de Cook, em fins de 1832, é um jovem ávido por aventuras que, quando menino lia Wonders of the World, discutia com outros meninos a veracidade das afirmaçóes desse livro e ansiava por conhecer lugares remotos. Finalmente, Darwin estava em uma terra selvagem, onde a saudação dos habitantes - situados na ponta de um penhasco por sobre o mar e, em parte, dissimulados pela selva consistia em agitar seus farrapos e lançar um grito prolongado e sonoro.

O que mais impressiona Darwin é a distância entre a civilização e a selvageria. Ele não pode acreditar que a diferença entre um selvagem e um homem civilizado seja maior do que a diferença entre um animal selvagem e um doméstico, uma vez que o homem teria o poder de aperfeiçoar-se, ao contrário do animal. Observa os fueguinos com um misto de medo e fascínio. A atitude dos nativos lhe parecia abjeta; porém, quando recebem pedaços de pano vermelho que amarram ao pescoço convertem-se, rapidamente, em "bons amigos". Excelentes mímicos, com uma linguagem que não poderia ser chamada de articulada, os selvagens pintados que pediam facas e se assemelhavam a demônios saídos de uma ópera, eram muito semelhantes aos famosos Patagões do Estreito de Magalhães.

Apesar da imagem negativa dos Haush, para o naturalista inglês, eles eram, sem dúvida, uma raça superior aos atrofiados, miseráveis e desafortunados Yamana. Estes, sim, podiam ser considerados os seres humanos mais abjetos da terra. Nas proximidades da ilha Wollaston, Darwin depara-se com uma canoa com seis fueguinos praticamente nus. Uma mulher, inclusive, estava absolutamente nua, apesar do frio e da chuva torrencial que escorria por sobre seu corpo. Em outra baía, uma mulher se aproxima, por curiosidade, do navio e ali permanece, a uma curta distância, por longo tempo, amamentando um menino recém nascido nos braços, enquanto a chuva gelada caía sobre seu peito nu e sobre o corpo, também nu, da criança. São cenas de um primitivismo que nada tem de bucólico. Para Darwin tratava-se de selvagens infelizes, atrofiados em seu crescimento, com rostos repugnantes lambuzados de tinta branca, pele suja e oleosa, cabelo desgrenhado, vozes desconcertantes e gestos violentos.

Os fueguinos eram, de acordo com essa classificação imperial, pessoas que não podiam conhecer o sentimento de ter uma casa e, muito menos, uma inclinação doméstica. Sua existência nômade e infeliz era puro esforço de sobrevivência. No entanto, a experiência com Jemmy Button comprovava que era possível educar esses exemplares humanos que mais pareciam habitantes de outro mundo. Seriam os fueguinos iguais aos europeus? De onde se originavam? Por que haviam abandonado as terras do norte e se mudado para uma das regiões mais inóspitas do globo? Por que razão viviam nessas condiçôes miseráveis? Deviam, pelo menos, desfrutar de alguma felicidade em sua sobrevivência, reflete Darwin, uma vez que não pareciam diminuir de número.

Darwin destaca o caráter global dos exemplos comparativos ao comparar os fueguinos com os grupos insulares dos mares ao sul do Oceano Pacífico; com os esquimós que dormem em choças subterrâneas; com algumas tribos da África meridional que se alimentam de raízes e com o aborígene australiano que sobe em árvores e dispõe do bumerangue e de lanças para caçar animais selvagens. E a terrível condição dos fueguinos - os seres humanos mais degradados do mundo -, não poderia mudar de imediato porque a perfeita igualdade entre os indivíduos que compunham suas diversas tribos deveria retardar, por longo tempo, o desenvolvimento de sua civilização.

Essa imagem radical da miséria, registrada em seu diário de viagem e transmitida em cartas dirigidas, em março de 1833, ao professor Henslow e a sua irmã Caroline ("sinto um desgosto profundo só de escutar o som das vozes desses pobres selvagens") ${ }^{21}$ acompanhará Darwin por muitos anos, senão até sua morte. Volta a mencioná-la nas páginas finais de seu livro The Descent of a Man, publicado em 1871, quando assinala que: 
A principal conclusão deste trabalho, ou seja, que o homem descende de alguma forma inferior de organização, será, lamento pensar, extremamente desagradável para muitos. Mas, dificilmente pode haver dúvida de que somos descendentes de bárbaros. Jamais esquecerei do espanto que senti, quando vi, pela primeira vez, um grupo de nativos da Terra do Fogo em um recanto selvagem da costa, sobretudo porque, instantaneamente, esta reflexão invadiu minha mente: "nossos ancestrais eram assim...". ${ }^{22}$

$\mathrm{Na}$ continuação do relato são acrescentadas "informações" que caracterizam as oscilações do pai do evolucionismo:

Eles [os fueguinos-yamana] não possuíam praticamente nenhuma habilidade e, como animais selvagens, sobreviviam do que podiam apanhar ou capturar; não tinham governo e não eram misericordiosos com ninguém que não fosse de sua pequena tribo. Aquele que tenha visto um selvagem em seu próprio território não se sentiria muito envergonhado se forçado a admitir que o sangue de uma das mais humildes criaturas corre em suas veias.

De minha parte, eu seria descendente daquele pequeno macaco heróico que enfrentou um terrível inimigo para salvar a vida de seu dono - ou de um velho babuíno que, descendo as montanhas, carregou em triunfo seu jovem parceiro fugindo de uma matilha de cães surpresos - e não, de um selvagem que se delicia em torturar seus inimigos, oferece sacrifícios sangrentos, pratica o infanticídio sem remorso, trata suas mulheres como escravas, ignora a decência e é assombrado pelas superstiçôes mais grosseiras. Um homem deve ser perdoado por ter orgulho de ter ascendido, ainda que não por esforço próprio, ao cume da escala orgânica; e o fato de haver subido assim, ao invés de ter sido primitivamente [aboriginally, no original] colocado lá, pode dar-lhe a esperança de um destino ainda mais elevado em um futuro distante. ${ }^{23}$

Paralelamente, Darwin recebia notícias das transformaçōes do fim do mundo resultantes da evangelização inglesa e seguia com atenção a trajetória do missionário anglicano Thomas Bridges, entre os fueguinos. Chega a entusiasmar-se com o trabalho da South American Missionary Society, doa cinco libras para os fundos da instituição e pede para ser admitido como membro honorário. No início de 1870, escreve a seu amigo Sullivan, ex-tenente do Beagle e agora responsável por arrecadar fundos para a sociedade missionária: "O sucesso da Missão na Terra do Fogo é maravilhoso e me encanta. Embora eu sempre tenha profetizado seu fracasso total, é um grande êxito". ${ }^{24}$

As ambivalências de Darwin em relação aos fueguinos - a meio caminho, segundo ele, entre os seres humanos e os animais selvagens - devem ser entendidas, como explica George Stocking, no contexto do renascimento religioso e da revolução industrial que reafirmava a superioridade dos valores morais protestantes ingleses diante das culturas primitivas. De acordo com Stocking, na época da viagem do Beagle, Darwin compartilhava com seus contemporâneos um difuso lamarckianismo, combinado com traços de uma perspectiva cristã tradicional. Por outro lado, emergia um racialismo que rejeitava a interação biocultural lamarckiana e subordinava a cultura à raça, questionando o valor da especulação social do ponto de vista evolucionista. ${ }^{25}$ Frases de Darwin como "dificilmente poderíamos nos colocar na posição desses selvagens e compreender suas ações", seriam menos uma declaração de relativismo cultural do que um posicionamento ambivalente face à suposta igualdade dos seres humanos. Em todo caso, para Darwin, até os selvagens do fim do mundo poderiam ser educados por missionários cristãos para participar da civilização, como comprovava o caso dos cativos fueguinos.

Quando Darwin está em Puerto Hambre, no Estreito de Magalhães, dirigindo seu olhar para o sul, registra em seu diário uma impressão do fim de mundo: "os canais distantes, entre as montanhas, pareciam, com seu aspecto sombrio, conduzir para além dos confins deste mundo" ${ }^{26}$ Ainda ecoa, nesta formulação, a noção de uma finisterra ${ }^{27}$ que navega em direção a seu ocaso. Já não é possível, em nossa era de comunicação global, pensar na existência de um "fim de mundo". Suas características fundamentais, no tempo de Darwin, eram a condição periférica, a distância dos centros civilizados, o isolamento, a dificuldade de comunicação, o caráter agreste da natureza, a população escassa e a presença mínima de estrangeiros. Somente por inércia, colonialismo mental, ou pelas vantagens materiais do turismo se prossegue pensando na realidade do fim do mundo. 
Será que, para os índios fueguinos, esse território significava "o fim do mundo"? Como e por que se constroem metáforas de "fim"? O que se pode concluir? Como seria possível pensar em uma geografia da relatividade? Para Darwin, o espaço não é meramente uma extensão física, mas, uma geografia simbólica. Quem se deleita com o contraste entre o azul berilo das geleiras e o branco da neve que as recobre, estabelece um curioso vínculo entre a solidão geográfica e a selvageria humana. A vasta solidão, a selva intocada pelo ser humano (entenda-se, pelos "europeus") produz cenas inesquecíveis em que o corpo é transportado a regióes transcendentes. Mas, sintomaticamente, tais territórios do sublime estão habitados por selvagens.

Vale a pena transcrever as conclusões de Darwin - esse romântico cientista viajante - que ilustram a sua consciência das transformaçôes efetuadas no mundo pela filantropia inglesa:

O mapa do mundo deixa de ser um espaço em branco; ele se torna um quadro repleto das mais variadas e animadas figuras. Cada parte assume sua dimensão própria: continentes já não são vistos como ilhas, nem ilhas consideradas como meras partículas, uma vez que são, de fato, maiores que qualquer reino da Europa. África, Américas do Norte e do Sul são nomes que soam bem e facilmente pronunciáveis. Porém, é apenas quando se navega, durante semanas, ao longo dos recantos de suas costas, que se torna possível ficar completamente convencido da grandeza dos espaços, em nosso imenso mundo, que esses nomes implicam... Observando o seu estado atual, seria impossível não criar grandes expectativas em relação ao progresso futuro de quase todo o hemisfério... Melhorias nos Mares do Sul em consequência da introdução do Cristianismo... transformações realizadas pelo espírito filantrópico da Nação Britânica... ${ }^{28}$

\section{Orundellico-Jemmy Button}

Os fueguinos tinham sido transportados à Inglaterra com o objetivo declarado de serem educados na cultura inglesa. Isto incluía, entre outras coisas, o aprendizado do inglês, dos civilizados costumes oitocentistas dos europeus, do cristianismo e do uso de ferramentas. Logo se percebeu a dificuldade de levar a cabo o projeto: imitar os gestos dos navegadores ingleses era mais fácil do que aprender seu idioma. Boat Memory, o mais adaptado dos fueguinos e, por conseguinte, o preferido de FitzRoy, apesar de todas as vacinas, morreu de varíola, o que fez com que o comandante se sentisse diretamente culpado por ter "abreviado sua existência". Os três restantes foram enviados a um colégio nos arredores de Londres, tendo sido, no momento oportuno, apresentados ao Rei e à Rainha da Inglaterra. Neste intercâmbio entre a civilização e a selvageria domesticada manifestam-se elementos da sociedade do espetáculo que, em breve, resultará na exibição de fueguinos em zoológicos humanos.

Por outro lado, eles são bem tratados, alimentados e vestidos, pois deverão retornar à sua terra para divulgar as vantagens da civilização inglesa. É evidente que a nobre intenção de FitzRoy de devolvê-los à sua terra natal - ideia inicialmente rejeitada pelo Almirantado devido aos custos, mas, finalmente, aprovada - estava relacionada à necessidade de se estabelecer pontos de contato entre os ingleses e os aborígenes da Terra do Fogo, simplificando, com isso, a comunicação entre as culturas e as tarefas dos expedicionários. FitzRoy deixou isto claro em uma carta escrita em Londres, em 23 de maio de 1831, onde assinalava que "esperava ver essas pessoas tornarem-se úteis como intérpretes e em condições de promover, entre seu conterrâneos, uma atitude amigável para com os ingleses, ou mesmo contatos regulares com eles" ${ }^{29}$ Contudo, também neste aspecto, os resultados não seriam aqueles esperados pelos ingleses.

Dependemos inteiramente dos relatos ingleses para obter detalhes sobre a segunda viagem do Beagle à Terra do Fogo. Sem dúvida o comandante estava consciente da magnitude da mudança. O "Sul" se lhe afigurava como uma terra selvagem, como escreveu de Montevidéu, à sua irmã, em 4 de dezembro de 1832: "estou, mais uma vez, deixando o mundo semicivilizado e retornando às regiōes bárbaras do sul" ${ }^{30}$ Em 20 de janeiro de 1833, antes de chegar a Wulaia, os fueguinos avistaram índios Haush, os primeiros aborígenes que viam depois da estada na Inglaterra. FitzRoy estava atento à reação de suas mascotes e foi, de fato, com alegria que percebeu que York Minster considerava tais exemplares como "yapoos", 
"grandes macacos", enquanto Fuegia Basket estava tão chocada e envergonhada que se recusava a olhálos pela segunda vez; Jemmy Button, por sua vez, assegurava que seu grupo era muito diferente desses índios maus e sujos. Intervém neste mecanismo de diferenciação o conceito freudiano de "narcisismo das pequenas diferenças", reforçado pelo fato de os fueguinos encontrarem-se no navio inglês.

O dia estava lindo quando os cativos chegaram a Wulaia carregados de presentes inúteis para a sua reinserção no contexto fueguino. De nada serviriam as taças de vinho, as bandejas de chá, as finas roupas de cama, o guarda-roupa de mogno, a não ser para desencadear a inveja e a pilhagem. York Minster rapidamente se apoderou de Fuegia Basket e Jemmy Button passou por situações constrangedoras, a julgar pelos relatos de FitzRoy e de Darwin.

De acordo com FitzRoy, Jemmy Button havia esquecido sua própria língua e York Minster passou a ser o intérprete, embora não falasse yamana. Apesar da presença desses mediadores culturais, os ingleses estabeleceram um espaço físico de neutralidade entre as culturas, contribuindo, com isso, para a desconfiança mútua. Poucas horas antes, Jemmy Button havia tomado conhecimento da morte de seu pai e, finalmente, reencontrava-se com sua mãe, duas irmãs e quatro irmãos que não via desde aquela manhã de 1830 quando, ainda menino, desaparecera em um barco chegado de longe. A mudança em seu aspecto exterior era notável. Darwin descreve-o como "baixo, atarracado e gordo, mas vaidoso em relação à sua aparência; costumava, sempre, usar luvas, trazia o cabelo bem aparado e preocupava-se em não sujar seus sapatos, muito bem engraxados" ${ }^{31}$ De repente, aparecia vestido, mais gordo, já adolescente, sem falar sua língua e rodeado de pessoas estranhas. Os ingleses aguardavam o abraço emocionado da família, mas, para decepção geral, a mãe praticamente nem olhou para o filho pródigo, voltando à sua canoa para cuidar dos alimentos. Suas irmãs também se retiraram de imediato, enquanto os irmãos rodeavam-no, observando-o em silêncio. Para FitzRoy, até os animais demonstravam mais animação e ansiedade ao se reencontrarem; Jemmy ficou muito aflito. Para aumentar sua confusão e decepção, não conseguia falar com seus irmãos, exceto algumas frases soltas nas quais predominava o inglês. ${ }^{32}$ Darwin confirma a informação do comandante, registrando que não houve demonstração de afeto e que o encontro foi menos interessante do que entre cavalos (mais adiante veremos os comentários da antropóloga Anne Chapman, em relação a este reencontro familiar).

A "confusão" indica que se trata de um novo momento na relação entre as culturas. São mudanças significativas no fim do mundo: nunca antes um fueguino havia voltado à sua comunidade após um processo tão prolongado de adaptação na Europa.

A ambiguidade marca o sujeito da dupla consciência, que oscila entre dois mundos. Umas das primeiras ações do jovem que acreditava em sonhos, foi vestir sua mãe e irmãos, agora parte da família Button. Nesta e em outras ações civilizadoras nota-se a posição ambígua de Jemmy como mediador cultural; tem que mostrar serviço aos ingleses, mas, para seus parentes, não fica claro porquê. Para que serve andar vestido na Terra do Fogo, se a umidade da roupa adere ao corpo e é mais nociva à saúde do que o óleo de baleia e a pintura? Os objetos são desejados, mas não solicitados de modo amável, como convém a uma sociedade civilizada: são exigidos, roubados ou arrancados com ameaças. $\mathrm{O}$ missionário Matthews não consegue permanecer entre esses "absolutos selvagens" que, dia e noite, exigem a entrega de seus bens: "Yammerschooner" é a palavra mais empregada pelos fueguinos nos encontros culturais. De acordo com Darwin, era muito fácil agradá-los, porém muito difícil satisfazê-los. Em coro repetiam "Yammerschooner" (give me). Jemmy se desculpa com FitzRoy: "Meu povo muito mau; grandes tolos; sabem absolutamente nada, completamente idiotas", 33 confirmando a avaliação do comandante de que os yamana eram semelhantes aos piores índios, aos quais York Minster se referia como "macacos-sujos-tolos-não homens".

Em 26 de fevereiro de 1833, o Beagle parte em direção às Ilhas Malvinas. Um ano depois estão de volta à Terra do Fogo. À distância, FitzRoy observa um aborígene que lhe parece conhecido, mas não consegue identificá-lo. Era Jemmy Button, nu, magro, desgrenhado, sujo. "Que mudança!", exclama, condoído, o comandante. Darwin acrescenta um detalhe que explica a dificuldade na identificação: a ver- 
gonha. Segundo o naturalista, o índio aproximou-se de costas, pois estava envergonhado e só foi possível reconhecê-lo bem próximo ao navio. Vestem-no e ele almoça educadamente com o comandante, utilizando corretamente o garfo e a faca. FitzRoy atribui a aparência abatida e miserável de Jemmy a alguma doença, mas este o surpreende dizendo que estava "saudável, nunca estivera melhor", ${ }^{44}$ que nunca estivera doente, nem sequer por um dia, que estava feliz e que não desejava mudar seu modo de vida.

$\mathrm{Na}$ verdade, Jemmy Button não desejava retornar a "Inglan" [Inglaterra]. O que o prendia àquelas terras geladas? Darwin chega ao cúmulo de sugerir que Jemmy Button não desejava voltar porque havia encontrado uma esposa que o aguardava, nervosa, na canoa. Relata, também, que o comandante se ofereceu para levá-lo de volta à Inglaterra, porém, para surpresa geral, a oferta foi recusada, de imediato, por Jemmy. Das Ilhas Malvinas, Darwin narra este episódio para sua irmã Catherine, em carta de 6 de abril de 1834:

Nós, então navegamos ao largo da costa e completamos a Carta [marítima] do lado oriental. Quando concluímos a tarefa, depois de visitarmos algumas das ilhas meridionais, alcançamos o magnífico cenário entre o Canal de Beagle e a terra de Jemmy Button. Mal pudemos reconhecer o pobre Jemmy; ao invés do rapaz forte, limpo e bem vestido que havíamos deixado, encontramos um selvagem nu, magro e abatido. York e Fuegia haviam se mudado, alguns meses antes, para a sua própria terra, não antes de York ter roubado todas as roupas de Jemmy. Agora, ele não tinha mais nada, a não ser um pedaço de cobertor em volta da cintura. O pobre Jemmy ficou tão feliz ao nos ver e, com a sua habitual delicadeza, trouxe diversos presentes (peles de lontra, mais valiosas para eles, do que para nós) para seu velho amigo. O comandante se ofereceu para levá-lo à Inglaterra, mas para a nossa surpresa, ele, prontamente, recusou: à noite, sua jovem esposa chegou ao seu lado e esta era a razão da recusa. Ele estava muito contente; um ano antes, no auge de sua indignação ele dissera que "seu povo não sabia nada - malditos tolos"; agora, eles eram pessoas muito boas, com abundância de alimentos e todos os luxos da vida.

Jemmy e sua esposa, muito felizes, foram embora remando em sua canoa cheia de presentes. $\mathrm{O}$ mais curioso é que Jemmy, ao invés de recuperar sua língua materna, tinha ensinado a todos os amigos um pouco de inglês: "J. Button's canoe and Jemmy's wife come" ["a canoa de J. Button" e "a esposa de Jemmy está chegando"]; "give me knife" [dê-me a faca] etc. eram faladas por vários deles." 35

Para além do retorno à vida selvagem, Jemmy Button havia se reintegrado a uma existência comunitária, na qual tinha seu lugar. Embora não se tenha certeza de que a experiência europeia tenha lhe proporcionado algum prestígio extra entre os fueguinos, esse índio yamana seria, até a sua morte, uma referência para os ingleses.

FitzRoy estava consciente do fracasso de seu experimento com os fueguinos e se contenta com a possibilidade de algum pequeno benefício no futuro, como a ajuda a náufragos, por parte dos filhos de Jemmy Button. Em contrapartida, Darwin e Hamond consideram que o experimento foi um fracasso completo. Depois de 58 meses de viagem, 43 dos quais passados na América do Sul, o Beagle regressou à Inglaterra, em 2 de outubro de 1836, desta vez sem nenhum índio fueguino a bordo, completando, assim, uma das mais importantes viagens da história da navegação moderna.

A devolução de Jemmy Button, Fuegia Basket e York Minster a seu território confirma que a revelação geográfica da Terra do Fogo estava muito avançada, diferentemente da "revelação humana", processo muito mais complexo do que FitzRoy poderia imaginar. Por certo, os exames da frenologia que indicavam a rápida ou lenta assimilação dos costumes ingleses pelos fueguinos, não foram suficientes, como sugere a negativa de Jemmy Button em voltar à Inglaterra.

Fundamentada nas liçôes do relativismo cultural, a antropóloga Anne Chapman se esforça sistematicamente, com a típica boa vontade dos antropólogos, em defender os nativos da Terra do Fogo das acusações dos ingleses. Argumenta que os fueguinos não precisavam de chefes nem de governo, que Darwin não compreendeu que "sentir-se em casa", para eles, podia significar uma praia coberta de cascalhos, ou uma extensão de areia com rochas cobertas de mexilhões e focas descansando, ou, ainda, a canoa onde a família passava a metade do tempo - com "fogão", água potável, um ou dois cães, uten- 
sílios domésticos e de caça. ${ }^{36}$ Não só os Yamana tinham um forte sentimento de lar e de apego por seu território, afirma Chapman, como mantinham laços de família, para a qual ambos os sexos contribuíam com o trabalho básico. Página após página Chapman desmente Darwin: de fato, ele não tinha entendido, por não dominar a língua yamana, expressões como "yammerschonner", que podia significar "seja gentil conosco"; ${ }^{37}$ Jemmy Button não havia esquecido sua língua nativa; os Yamana, por respeito, não deviam evocar ou falar sobre os mortos em público, tampouco expor suas emoções publicamente.

Em todo caso, Jemmy Button havia se tornado uma referência fundamental para os ingleses quando, em 1848, Allen Gardiner, comandante aposentado da Marinha Britânica e fundador da Patagonian Missionary Society, desembarcou na Ilha Picton com planos de evangelizar os indígenas. De onde vem essa vontade de sair pelo mundo para evangelizar? Por que abandonar a segurança do lar e aventurar-se por regiōes desconhecidas? Qual é a legitimidade de um grupo evangelizador, sobretudo quando levamos em consideração que se trata de uma entidade privada - a Patagonian Missionary Society (posteriormente, South American Missionary Society) - sem nenhum apoio do Almirantado inglês, nem de outras entidades religiosas? Com escassos recursos e sem apoio logístico, a primeira incursão de Gardiner pelos canais da Terra do Fogo foi um fracasso.

Três anos depois, em 1851, enquanto em Londres se celebrava a primeira Exposição Universal no Palácio de Cristal, Gardiner desembarcou novamente na inóspita ilha Picton com seis companheiros e com a esperança de encontrar Jemmy Button. Mas, o grupo esqueceu a munição a bordo do Ocean Queen, que seguiu viagem. Indefesos diante da hostilidade dos aborígenes, incapazes de caçar animais e sem conseguir o esperado contato com Jemmy Button, os missionários morreram de frio e de fome, nos arredores da Ilha Navarino.

Este episódio dramático desencadeou, na Inglaterra, um fervor missionário que se materializou no envio da escuna Allen Gardiner, em outubro de 1854, às Ilhas Malvinas, sob o comando de William Parker Snow. Em seu livro A Two Years cruise off Tierra del Fuego, The Falkland Islands, Patagonia and the River Plate: A Narrative of Life in the Southern Seas, publicado em 1857, o comandante Snow expressa as contradiçôes da descoberta do fim do mundo, em meados do século XIX. Narra a história gloriosa dos marinheiros ingleses que, com coragem e dedicação, abriram esses espaços "escondidos", temidos e longínquos - essa terra incognita - à ciência. FitzRoy aparece, consequentemente, como o herói de uma gesta náutica, responsável pela exploração daquela que é geralmente considerada como a costa mais selvagem e tempestuosa do mundo. Também era digno de louvor, o plano de FitzRoy de devolver os índios cativos à sua própria terra, na esperança de levar algum benefício à condição degradada dos fueguinos. Mas, para o comandante Snow, aqui teriam começado os problemas, uma vez que não era suficiente que estranhos, como que caídos do céu, levassem aborígenes à mais alta manifestação da dignidade humana (a Inglaterra) e depositassem-nos novamente em seu território, anos depois, sem nenhuma preocupação com seus destinos. Era compreensível, de acordo com Snow, que os índios voltassem a seu estado selvagem e que a viagem à Inglaterra tenha sido, para eles, como um sonho.

Snow critica duramente o projeto da Patagonian Missionary Society de deslocar fueguinos para a Ilha Keppel. Alega, por exemplo, que a Missão pretende importar nativos para a ilha, com a desculpa de instruí-los nas práticas úteis da civilização, mas que, na verdade, servirão para cuidar do gado e para outras tarefas semelhantes. Não se deve deslocar nativos de seu território para escravizá-los, mas, oferecer-lhes ajuda em seu próprio espaço. Os selvagens, escreve Snow, podem ser degradados, miseráveis e desafortunados, mas têm coração, como os ingleses, e é necessário respeitar a sua vontade, mesmo que não pensem da mesma forma que os missionários.

Apesar de tudo, Snow reconhece de modo explícito o papel fundamental de Jemmy Button para o triunfo do projeto missionário. Esse fueguino, "semicivilizado", é o ponto de referência indispensável, um mediador cultural, um indivíduo potencialmente amigo no extremo sul do mundo. Ninguém tinha informaçôes sobre o paradeiro de Jemmy Button, quando, ao aproximar-se da Ilhota Button (nome 
dado por FitzRoy), o comandante Snow tem a ideia de mostrar a bandeira inglesa do barco a alguns índios canoeiros, com a vaga esperança de encontrá-lo naquela área e não ter que seguir até Wulaia.

Como o que se está buscando é um personagem, o encontro causa estranhamento. Quem se apresenta diante do comandante Snow como "Jam-mes Button, me" não é o adolescente parcialmente educado na Inglaterra, mas, um adulto corpulento, selvagem e desgrenhado. ${ }^{38}$ Passados mais de vinte anos de seu regresso à Terra do Fogo, Jemmy Button ainda fala inglês e se reencontra com um mundo distante: imagens e nomes, palavras entrecortadas, gestos, rituais, roupas, comidas, sabores, odores. Jemmy é agora o personagem de uma história; existem, até mesmo, desenhos dele, quando jovem (incluídos no livro de FitzRoy, de 1839) que o surpreendem: "Os retratos dele e de outros fueguinos fizeram-no, alternadamente, rir e entristecer-se, como se os dois personagens que representava - o selvagem e o civilizado -, surgissem diante de seus olhos" ${ }^{39}$ A esposa do comandante lhe traz à memória a beleza das mulheres inglesas, tão diferentes das suas duas mulheres, nuas e de cor acobreada, que lhe deram três filhos. Agrada-lhe conversar com o comandante Snow, apesar da dificuldade com o idioma, e tem boas lembranças da Inglaterra; porém, recusa-se terminantemente a ir-se, com sua família, para as Ilhas Malvinas. Aceita vestir-se e alimentar-se no navio, dando ao comandante a impressão de "um imenso babuíno vestido para a ocasiāo". ${ }^{40}$ Contudo, ao voltar no dia seguinte, a roupa de Jemmy Button estava completamente suja de terra e, agora, ele parecia, segundo Snow, "mais hediondo e deplorável do que jamais imaginara". ${ }^{41}$

Não é apenas uma única pessoa que visita o barco no meio da madrugada. São como uns cem fueguinos e todos queriam algo, informa um preocupado Snow. Temos aqui um problema crucial no contato entre culturas: a desigualdade das imagens. O navio inglês, no fim do mundo, representa um Palácio de Madeira repleto de bens. Todos querem presentes, inclusive os irmãos de Jemmy Button e os inimigos deste que se misturam à multidão. A frase dos fueguinos é clara e extraordinariamente expressiva: "Ingliss come. Ingliss give. Ingliss plenty". ${ }^{42}$

Não há limite quando se instaura a imagem da abundância. As facas e outros objetos nunca satisfazem plenamente e Jemmy Button nada faz quando seus irmãos tentam arrancar as roupas do comandante Snow. Tomado por grande nervosismo, ele ordena aos marujos que levantem âncora e anuncia a partida conseguindo que os fueguinos abandonem o barco imediatamente -, o que indica que a situação, praticamente, estava fora de controle. Ninguém quer viajar no navio dos ingleses, mas a imagem da abundância dos objetos europeus já é responsável por conflitos culturais que tendem a agravar-se na Terra do Fogo.

Snow justificou seu insucesso na tentativa de transportar fueguinos às Ilhas Malvinas, argumentando que era necessário respeitar as suas vontades. De acordo com o comandante, Jemmy Button tinha experimentado "as doçuras e - como poderiam ser para ele - os amargores da alta civilização" ${ }^{43}$ e havia rejeitado energicamente seu pedido e o do catequista Garland-Phillips para mudar-se para as Ilhas Malvinas. Por outro lado, ainda de acordo com Snow, não se devia transportar fueguinos para longe de seu entorno sem que, antes, tivessem aprendido a língua inglesa e adquirissem plena consciência do que significava a mudança de território e de costumes.

O fracasso de Snow proporcionou as condições para que o reverendo George Packenham e sua família fossem transferidos para as Ilhas Malvinas e que o comandante fosse destituído, rapidamente, pelo próprio reverendo que se encarregou pessoalmente, e com mão de ferro, das atividades da Patagonian Missionary Society. Jemmy Button havia sido localizado e, finalmente, convencido por Despard a estabelecer-se por seis meses nas Ilhas Malvinas, acompanhado por uma de suas esposas e pelos três filhos. Começava assim, em meados de 1858, a transferência de fueguinos para a Missão na Ilha Keppel, primeira etapa de uma experiência missionária que terminaria no massacre de ingleses em Wulaia, a 6 de novembro de 1859, no qual Jemmy Button foi apontado como instigador da matança pelo único sobrevivente, o cozinheiro Alfred Coles, embora nada tenha sido provado em um julgamento posterior. Não interessa, aqui, detalhar o episódio conhecido como "o massacre de Wulaia” e seus desdobramentos, mas, simplesmente sugerir que as exigências dos missionários e a escassez de "presentes" foram, certamente, elementos decisivos na matança. O enfrentamento radical entre as culturas é o resultado 
dos modos de vida introduzidos pelo homem branco que não obtém os resultados imaginados por nenhuma das partes envolvidas, obrigando a que se repensasse o rumo evangelizador da Missão e que fosse anunciado o projeto de colonização do fim do mundo.

Jemmy Button faleceu pouco tempo depois, contaminado por uma das muitas epidemias que dizimavam os fueguinos. Tinha aproximadamente 50 anos (c. 1815-1864). Ao longo do século XX, marcado por conflitos de identidade, ressurgiu das cinzas como a fênix e adquiriu uma inesperada relevância simbólica. O escritor Benjamin Subercaseaux dedicou a este personagem "chileno" um volumoso romance, Jemmy Button ${ }^{44}$ e o pesquisador e pastor batista Arnoldo Canclini publicou o romance histórico El fueguino. Jemmy Button y los suyos. ${ }^{45}$ Jemmy Button é um dos protagonistas centrais do romance de Sylvia Iparraguirre, La tierra del fuego, ${ }^{46}$ enquanto Francisco Hervé propõe, na ficção histórica Soy Jemmy Button, el salvaje, ${ }^{47}$ "que este homem se constitua em uma figura emblemática de nossa história [chilena]". ${ }^{48}$ Alguns autores, como Arnoldo Canclini, chamam o yamana Jemmy Button de Omoylume, enquanto outros, como Francisco Hervé, de Orundellico.

Para a antropóloga Anne Chapman, trata-se de um modelo de multiculturalismo contemporâneo:

O jovem Jemmy Button apresenta-se como um fueguino muito apegado aos seus "compatriotas", embora, às vezes, furioso com eles; muito afeiçoado aos seus amigos ingleses, embora relutante em voltar à Inglaterra. Ele adquire o fascínio de um símbolo para o presente e para o futuro: uma pessoa apaixonada por seu "país" que, simultaneamente, recebe com prazer e hospitalidade o mundo exterior, em seu caso, a Inglaterra. ${ }^{49}$

Talvez seja inadequado mencionar neste contexto a já desgastada palavra "multiculturalismo", uma vez que ela pressupõe uma ideologia de antiassimilação, de fragmentação e de culto à diferença. ${ }^{50}$ Contudo, o exemplo de Jemmy Button coloca-nos diante de um elemento constitutivo da modernidade: a ampla circulação de indivíduos, ideias e objetos. Devemos lembrar, no entanto, que os grupos humanos deslocam-se de modo desigual pelo mundo, na medida em que as chamadas "cidades mundiais" e os "países mundiais" atraem grande parte dos fluxos migratórios. Apesar de todas as restrições e tentativas de controlar as fronteiras, os polos migratórios converteram-se em espaços da tolerância.

Os intelectuais ocupam um lugar especial neste extenso e intenso deslocamento de pessoas pelo mundo. Interessa-me destacar especificamente o fenômeno do "duplo pertencimento" espacial. Os críticos têm se ocupado amplamente com a questão da "dupla consciência" (Paul Gilroy, Michel-Ralph Trouillot, Walter Mignolo) e muito menos com o "duplo pertencimento". Dificilmente o personagem do duplo pertencimento é um "cêntrico", mas, um periférico que se adapta ao novo contexto mantendo um forte vínculo com sua terra natal, experimentando os limites da pertença igualitária a várias culturas. Assim como é discutível que se possa pertencer a mais de duas ou três culturas no decorrer de uma única vida, torna-se suspeito o exemplo do declarado cosmopolitismo de Mario Vargas Llosa.

A possibilidade de pertencer a duas culturas é um privilégio, se comparamos a situação de intelectuais contemporâneos com o passado. No século XVI, o Inca Garcilaso de La Vega (Gómez Suárez de Figueroa), conhecido como "o príncipe dos escritores do Novo Mundo", só teve acesso à cultura espanhola por ser filho de um conquistador espanhol e de uma princesa inca. É evidente, no Inca Garcilaso, a vontade de manter uma dupla identificação: com o Império inca e com a Espanha. Hoje, já é possível, graças, sobretudo, à moderna tecnologia de transportes e comunicação, sentir-se em casa em mais de um lugar, contrariando o chamado "desenraizamento etnográfico" a partir do qual, de acordo com a clássica definição de Lévi-Strauss, o etnógrafo jamais volta a se sentir em casa em parte alguma, tornando-se psicologicamente mutilado.

Os intelectuais contemporâneos não dependem de uma dupla linhagem para serem representantes da cultura, no plural. Tzvetan Todorov, intelectual búlgaro-francês, afirma que, um dia, teve de reconhecer que já não era um estrangeiro em Paris. Descobriu que tinha uma vida interior em duas culturas, que pertencia a ambas e que se sentia à vontade tanto em Sófia quanto em Paris. Não era um francês 
como os outros e, sim, um exemplo de transculturação (para lembrar o neologismo criado, em 1940, pelo cubano Fernando Ortiz). Desde então, escreve Todorov em L'homme dépaysé, ${ }^{51}$ vive ao mesmo tempo fora e dentro: estrangeiro em sua casa (Sófia), em casa no estrangeiro (Paris).

Um caso semelhante é o do anglo-jamaicano Stuart Hall que reflete sobre a sua própria diáspora e sobre sua relação com a Inglaterra. Hall, tanto quanto Todorov, compreende que jamais será plenamente um inglês e se refere à experiência de estar dentro e fora, ou seja, no "estrangeiro familiar", como sendo uma condição típica da modernidade tardia.

Poderíamos multiplicar os exemplos, inclusive ilustrá-los com referências literárias, mas concluo com o chileno-norteamericano nascido em Buenos Aires, Ariel Dorfman, um modelo de biculturalismo, narrado em Heading South, Looking North - A Bilingual Journey. ${ }^{52}$ Dorfman viveu dez anos, quando criança, nos Estados Unidos e, durante esse tempo, recusou-se a falar a língua materna, negando, desta forma, sua condição híbrida que, hoje, entende como a única salvação possível para a espécie humana. Foi, nessa época infanto-juvenil, um defensor deslumbrado do american way of life até retornar ao Chile e se entregar com paixão à sua identidade chilena, durante o governo de Salvador Allende, repudiando o imperialismo norte-americano. Posteriormente retornou aos Estados Unidos. Não importam, aqui, os possíveis exageros ou distorções em relação à história, mas, a manifestação de um ideal de reconciliação cultural: a aceitação da condição híbrida. O que era impossível no caso oitocentista do yamana Jemmy Button - representante da dupla consciência, mas não do duplo pertencimento -, a admissão orgulhosa do pertencimento múltiplo, é no início do terceiro milênio ainda uma realidade distante, mas, um ideal, cada vez mais próximo.

Tradução: Fernando Luiz Vale e Castro. Revisão técnica e edição: Maria Aparecida Rezende Mota.

\section{Notas}

${ }^{1}$ Entrevista de Mario Vargas Llosa a Mànya Millen, O Globo, 23/09/2006, “Prosa e Verso”. p. 2.

${ }^{2}$ Ver DAVIS, Natalie Zemon. The Return of Martin Guerre. Cambridge: Harvard University Press, 1983.

${ }^{3}$ Jaime Roos, Álbum RepertórioAquello, Gravadora Orfeo, 19812007. Nota do Editor.

${ }^{4}$ Vilém Flusser (Praga, 1920 - Praga, 1991). Durante a Segunda Guerra, fugindo ao Nazismo, mudou-se para o Brasil, estabelecendo-se em São Paulo, onde atuou por cerca de 20 anos como professor de filosofia, jornalista, conferencista e escritor. A partir de 1960 inicia sua colaboração com a Revista Brasileira de Filosofia e aproxima-se de um círculo de intelectuais brasileiros de formação liberal. Publica seu primeiro livro, Língua e realidade, em 1963. Nota do Editor.

${ }^{5}$ Cf. KING, Phillipp Parker. Narrative of the Surveying Voyages of His Majesty's Ships Adventure and Beagle. Proceedings of the First Expedition 1826-1830, under the Command of Captain P. Parker King. London: Henry Colburn, 1839. Vol. I. p. 55-56.

${ }^{6}$ A denominação "fueguinos" para os povos aborígenes do arquipélago austral, trata-se, na verdade, de uma generalização meramente geográfica. Bitlloch informa que os fueguinos "dividem-se em dois grandes grupos completamente diferentes entre si. O primeiro, é constituído pelos selk’nam, u 'ona', e os haush, ou manekekn, habitantes da parte oriental e plana da ilha. Por suas características físicas, sua língua e seus costumes este grupo é totalmente semelhante às sociedades indígenas da Patagônia. O segundo grupo é formado pelos yamana ou 'yahgan' e os alakaluf, habitantes das costas fueguinas e das ilhas próximas, diferentes física, cultural e linguisticamente do primeiro e mais relacionados aos chonos, habitantes do arquipélago chileno. Enquanto o primeiro grupo era constituído por caçadores rudimentares e nômades que se deslocavam a pé, o segundo era composto por pescadores nômades que usavam canoas como meio de transporte e que praticavam uma economia coletora primitiva. Contudo, ambos possuíam algo em comum: uma economia baseada na mera apropriação". Cf. BITLLOCH, Eduardo. Tierra del Fuego en cuatro textos (del siglo XVIII al XX). Buenos Aires: Universidad de Buenos Aires, 1994. p. 8.

${ }^{7}$ No original: "In Memory of Commander Pringle Stokes R. N. / H. M. S. Beagle / Who died from the effects of the anxieties and hardships incurred while surveying the western shores of Tierra del Fuego 12-8-1828".

${ }^{8}$ Estudo da forma do crânio para determinar o caráter e a capacidade mental de um indivíduo. Nota do Tradutor.

${ }^{9}$ Cf. KING, Phillipp Parker. Op. cit., vol. I. p. 216. 
${ }^{10}$ James Cook (Yorkshire, Inglaterra, 27/10/1728 - Havaí, 14/02/1779), comandante da Marinha Real Britânica, foi explorador, navegador e cartógrafo, sendo considerado o descobridor da Austrália e da Nova Zelândia. Em sua primeira expedição ao Oceano Pacífico, iniciada em agosto de 1768, percorreu a rota do Atlântico sul, em direção ao Estreito de Magalhães, navegando ao largo da costa oriental da Terra do Fogo, no extremo sul da Patagônia, onde deu nome a diversos acidentes geográficos. Nota do Editor.

${ }^{11}$ Cf. KING, Phillipp Parker. Op. cit., vol. I. p. 416. No original: "Boat (Memory) was the best-featured Fuegian I had seen, and being Young and well made, was a very favourable specimen of the race; York (Minster) was one of the stoutest men I had observed among them; but little Fuegia (Basket) was almost as broad as she was high: she seemed to be so merry and happy, that I do not think she would willingly have quitted us. Three natives of Tierra del Fuego, better suited for the purpose of instruction, and for giving, as well as receiving information, could not, I think, have been found".

${ }^{12}$ Idem, ibidem, p. 444. No original: "We gave them a few beads and buttons, for some fish; and, without any previous intention, I told one of the boys in a canoe to come into our boat, and gave the man who was with him a large shining mother-of-pearl button. The boy got into my boat directly, and sat down. Seeing him and his friends seem quite contented, I pulled onwards, and, a light breeze springing up, made sail. Thinking that this accidental occurrence might prove useful to the natives, as well as to ourselves, I determined to take advantage of it. (...) 'Jemmy Button', as the boat's crew called him, on account of his price, seemed to be pleased at his change, and fancied he was going to kill guanaco, or wãnãkãye, as he called them - as they were to be found near that place".

${ }^{13}$ Idem, ibidem, p. 458-59. No original: "I had previously made up my mind to carry the Fuegians, whom we had with us, to England; trusting that the ultimate benefits arising from their acquaintance with our habits and language, would make up for the temporary separation from their own country. But this decision was not contemplated when I first took them on board; I then only thought of detaining them while we were on their coasts; yet afterwards finding that they were happy and in good health, I began to think of the various advantages which might result to them and their countrymen, as well as to us, by taking them to England, educating them there as far as might be practible, and then bringing them back to Tierra del Fuego".

${ }^{14}$ DARWIN, Charles. Autobiography. Cambridge: Icon Books, 2003. p. 36. No original: "The voyage of the Beagle has been by far the most important event in my life, and has determined my whole career".

${ }^{15}$ DARWIN, Charles. Narrative of the Surveying Voyages of His Majesty's Ships Adventure and Beagle. Vol. III. Journal and Remarks 1832-1836. London: Henry Colburn, 1839. p. 598, 601. No original: "Trust nothing to the memory"; "It is better to send home a few things well preserved, than a multitude in a bad condition".

${ }^{16}$ BROSSE, Jacques. La vuelta al mundo de los exploradores. Los grandes viajes marítimos, 1764-1843. Barcelona: Ediciones del Serbal, 1985. p. 16.

${ }^{17}$ DARWIN, Charles. Narrative of the Surveying Voyages of His Majesty's Ships Adventure and Beagle. Op. cit., vol. III. p. 236. No original: "Nor are they exempt from famine, and as a consequence, cannibalism accompanied by parricide".

${ }^{18}$ Idem, ibidem, p. 241. No original: "Captain FitzRoy has given an account of all the interesting events which there happened".

${ }^{19}$ DARWIN, Charles. Charles Darwin's Beagle Diary. Edited by Richard Darwin Keynes. Cambridge: Cambridge University Press, 2001. p. 450. No original: "Of individual objects, perhaps nothing is more certain to create astonishment than the first sight in his nature haunt of a barbarian - of man in his lowest and most savage state. One's mind hurries back over past centuries, and then asks, could our progenitors have been like these? - men, whose every signs and expressions are less intelligible to us than those to the domesticated animals; men, who do not possess the instinct of those animals, nor yet appear to boast of human reason, or at least of arts consequent on that reason. I do not believe it is possible to describe or paint the difference between savage and civilized men".

${ }^{20}$ Idem, ibidem, p. 121.

${ }^{21}$ No original: "I feel quite a disgust at the very sound of the voices of these miserable savages".

${ }^{22}$ Apud CHAPMAN, Anne. Darwin in Tierra del Fuego. Buenos Aires: Imago Mundi, 2006. p. 31-32. No original: "The main conclusion arrived at in this work, namely, that man is descended from some lowly organized form, will, I regret to think, be highly distasteful to many. But there can hardly be a doubt that we are descended from barbarians. The astonishment which I felt on first seeing a party of Fuegians on a wild and broken shore will never be forgotten by me, for the reflection at once rushed into my mind - such were our ancestors..."

${ }^{23}$ Idem, ibidem, p. 128-129. No original: "They [los fueguinos-yámana] possessed hardly any arts, and like wild animals lived on what they could catch; they had no government, and were merciless to every one not of their own small tribe. He who has seen a savage in his native land will not feel much shame, if forced to acknowledge that the blood of some more humble creature flows in his veins. For my own part I would as soon be descended from that heroic little monkey who braved his dreaded enemy in order to save the life of his keeper or from that old baboon, who, descending from the mountains, carried away in triumph his young comrade from a crowd of astonished dogs - as from a savage who delights to torture his enemies, offers up bloody sacrifices, practices infanticide without remorse, treats his wives like slaves, knows no decency, and is haunted by the grossest superstitions. Man may be excused for feeling some pride at having risen, though not through his own exertions, to the very summit of the organic scale; and the fact of his having thus risen, instead of having been aboriginally [sic] placed there, may give him hope for a still higher destiny in the distant future". 
${ }^{24}$ Apud HAZLEWOOD, Nick. Savage. The Life and Times of Jemmy Button. New York: Thomas Dunne Books, 2001. p. 342. No original: "The success of the Tierra del Fuego Mission is most wonderful, and charms me, as I had always prophesied utter failure. It is a grand success".

${ }^{25}$ STOCKING, George W. Victorian Anthropology. New York: The Free Press, 1987. p. 106.

${ }^{26}$ DARWIN, Charles. Charles Darwin's Beagle Diary. Op. cit., p. 188. No original: "The distant channels between the mountains appeared from their gloominess to lead beyond the confines of this world'.

${ }^{27}$ Do latim, finis terrae: ponto extremo de determinada região. Nota do Tradutor.

${ }^{28}$ DARWIN, Charles. Charles Darwin's Beagle Diary. Op. cit., p. 451-52. No original: "The map of the world ceases to be a blank; it becomes a picture full of the most varied and animated figures. Each part assumes its proper dimensions: continents are not looked at in the light of islands, or islands considered as mere specks, which are, in truth, larger than any kingdoms of Europe. Africa, or North and South America, are well-sounding names, and easily pronounced; but it is not until having sailed for weeks along small portions of their shores, that one is thoroughly convinced what vast spaces on our immense world these names imply. (...) From seeing the present state, it is impossible not to look forward with high expectations to the future progress of nearly an entire hemisphere. (...) Improvement of South Sea consequent on the introduction of Christianity... changes effected by the philanthropic spirit of the British Nation..."

${ }^{29}$ FITZROY, Robert. Narrative of the Surveying Voyages of His Majesty's Ships Adventure and Beagle. Appendix to Volume II. London: Henry Colburn, 1839. p. 91. No original: "I hoped to have seen these people become useful as interpreters, and be the means of establishing a friendly disposition towards Englishmen on the part of their countrymen, if not a regular intercourse with them".

${ }^{30}$ Apud HAZLEWOOD, Nick. Savage. The Life and Times of Jemmy Button. Op. cit., p. 117. No original: "I am again quitting the demi-civilised world and am returning to the barbarous regions of the south".

${ }^{31}$ DARWIN, Charles. Charles Darwin's Beagle Diary. Op. cit., p. 185. No original: "short, thick, and fat, but vain of his personal appearance; he used always to wear gloves, his hair was neatly cut, and he was distressed if his well-polished shoes were dirtied".

${ }^{32}$ FITZROY, Robert. Narrative of the Surveying Voyages of His Majesty's Ships Adventure and Beagle. Vol. II. Op. cit., p. 209.

${ }^{33}$ No original: "My people very bad; great fool; know nothing at all; very great fool".

${ }^{34}$ No original: "hearty, sir, never better".

${ }^{35}$ Darwin Correspondence Project. Letter 242, disponível em <http://www.darwinproject.ac.uk/entry-242>. No original:

"We then returned to the outside coast \& completed the Chart of the Eastern side: When this was finished after visiting some of the Southern islands we beat up through the magnificent scenery of the Beagle channel to Jemmy Buttons country. We could hardly recognize poor Jemmy; instead of the clean, well-dressed stout lad we left him, we found him a naked thin squalid savage. York \& Fuegia had moved to their own country some months ago; the former having stolen all Jemmy's clothes. Now he had nothing, excepting a bit of blanket round his waist. Poor Jemmy was very glad to see us \& with his usual good feeling brought several presents (otter skins which are most valuable to themselves) for his old friends. The Captain offered to take him to England, but this, to our surprise, he at once refused: in the evening his young wife came alongside \& showed us the reason. He was quite contented; last year in the height of his indignation, he said "his country people no sabe nothing-damned fools" now they were very good people, with too much to eat \& all the luxuries of life. Jemmy \& his wife paddled away in their canoe loaded with presents \& very happy. The most curious thing is, that Jemmy instead of recovering his own language, has taught all his friends a little English: 'J. Button's canoe \& Jemmy's wife come; 'give me knife' \&o was said by several of them".

${ }^{36}$ CHAPMAN, Anne. Darwin in Tierra del Fuego. Buenos Aires: Imago Mundi, 2006. p. 60.

${ }^{37}$ No original: "be kind to us".

${ }^{38}$ No original: "a stout, wild, and shaggy-looking man".

${ }^{39}$ SNOW, William Parker. A Two Years cruise off Tierra del Fuego, The Falkland Islands, Patagonia and the River Plate: A Narrative of Life in the Southern Seas. London: Longman, Brown, Green, Longmans \& Roberts, 1857. Vol. II, p. 38. No original: "The portraits of himself and the other Fuegians made him laugh and look sad alternately, as the two characters he was represented in, savage and civilized, came before his eye".

${ }^{40}$ No original: "a huge baboon dressed for the occasion".

${ }^{41}$ No original: "more hideous and deplorable than I could have imagined".

42 "Ingleses chegam, ingleses dão, ingleses têm". Nota do Editor.

${ }^{43}$ No original: "the sweets, or, as they might be to him, the bitters of high civilization".

${ }^{44}$ SUBERCASEAUX, Benjamin. Jemmy Button. Santiago: Editorial Ercilla, 1950. Edição definitiva, 1961. Nota do Editor.

${ }^{45}$ CANCLINI, Arnoldo. El fueguino. Jemmy Button y los suyos. Buenos Aires: Editorial Sudamericana, 1998. Nota do Editor.

${ }^{46}$ IPARRAGUIRRE, Sylvia. Buenos Aires: Editorial Alfaguara, 1998. Nota do Editor.

${ }^{47}$ HERVÉ, Francisco. Soy Jemmy Button, el salvaje. Santiago: Zig-Zag, 2003. Nota do Editor.

${ }^{48}$ Idem, ibidem, p. 9. 
${ }^{49}$ CHAPMAN, Anne. Darwin in Tierra del Fuego. Op. cit., p. XVI. No original: "Jemmy Button, a younger man, presents the figure of a Fuegian very attached to his 'countrymen' though at times furiously angry at them, very fond of his British friends, though unwilling to go back to England. He acquires the allure of a symbol for the present and the future: a person in love with his 'country' who simultaneously welcomes the outside world, in his case England'.

${ }^{50}$ KUPER, Adam. Culture. The Anthropologists' Account. Cambridge: Harvard University Press, 1999.

${ }^{51}$ TODOROV, Tzvetan. L’homme dépaysé. Paris: Seuil, 1996. Nota do Editor.

52 DORFMAN, Ariel. Heading South, Looking North - A Bilingual Journey. New York: Farrar, Straus \& Giroux, 1998. Nota do Editor.

\section{Referências bibliográficas}

BITLLOCH, Eduardo. Tierra del Fuego en cuatro textos (del siglo XVIII al XX). Buenos Aires: Universidad de Buenos Aires, 1994.

BROSSE, Jacques. La vuelta al mundo de los exploradores. Los grandes viajes marítimos, 1764-1843. Barcelona: Ediciones del Serbal, 1985.

CANCLINI, Arnoldo. El fuegino Jemmy Button y los suyos. Buenos Aires: Sudamericana, 1998.

CHAPMAN, Anne. Darwin in Tierra del Fuego. Buenos Aires: Imago Mundi, 2006.

DARWIN, Charles. Autobiography. Cambridge: Icon Books, 2003.

Charles Darwin's Beagle Diary. Edited by Richard Darwin Keynes. Cambridge: Cambridge University Press, 2001.

. Narrative of the Surveying Voyages of His Majesty's Ships Adventure and Beagle. Vol. III. Journal and Remarks 1832-1836. London: Henry Colburn, 1839.

. The Voyage of the Beagle. New York: The Modern Library, 2001.

DAVIS, Natalie Zemon. The Return of Martin Guerre. Cambridge: Harvard University Press, 1983.

FITZROY, Robert. Narrative of the Surveying Voyages of His Majesty's Ships Adventure and Beagle. Vol. II. Proceedings of the Second Expedition 1831-1836, under the Command of Captain Robert FitzRoy. London: Henry Colburn, 1839.

FITZROY, Robert. Narrative of the Surveying Voyages of His Majesty's Ships Adventure and Beagle. Appendix to Volume II. London: Henry Colburn, 1839.

HAZLEWOOD, Nick. Savage. The Life and Times of Jemmy Button. New York: Thomas Dunne Books, 2001. HERVÉ, Francisco. Soy Jemmy Button, el salvaje. Santiago: Zig-Zag, 2003.

HOMERO. Obras completas. Trad. L. Segalá. Barcelona: Montaner y Simón, 1927.

KING, Phillipp Parker. Narrative of the Surveying Voyages of His Majesty's Ships Adventure and Beagle. Vol. I. Proceedings of the First Expedition 1826-1830, under the Command of Captain P. Parker King. London: Henry Colburn, 1839.

KUPER, Adam. Culture. The Anthropologists' Account. Cambridge: Harvard University Press, 1999.

LUIZ, María Teresa y Monika SCHILLAT. La frontera austral. Tierra del Fuego, 1520-1920. Cádiz: Servicio de Publicaciones de la Universidad de Cádiz, 1997.

MARTINIC, Mateo. Historia del Estrecho de Magallanes. Santiago: Andrés Bello, 1977.

NICHOLS, Peter. Evolution's Captain. The Story of the Kidnapping That Led to Charles Darwin's Voyage aboard the Beagle. New York: Harper Collins, 2003.

PRIETO, Adolfo. Los viajeros ingleses y la emergencia de la literatura argentina. Buenos Aires: Sudamericana, 1996.

SLOTERDIJK, Peter. Esferas II. Globos. Trad. Isidoro Reguera. Madrid: Siruela, 2004.

SNOW, William Parker. A Two Years cruise off Tierra del Fuego, The Falkland Islands, Patagonia and the River Plate: A Narrative of Life in the Southern Seas. 2 Vols., London: Longman, Brown, Green, Longmans \& Roberts, 1857.

STOCKING, George W. Victorian Anthropology. New York: The Free Press, 1987. 


\title{
RESUMO
}

A oposição entre "dentro" e "fora", que por muito tempo norteou a imagem que temos do espaço, se defronta hoje com renovados desafios territoriais. Enquanto uma vertente da reflexão contemporânea sobre o espaço destaca a importância de perspectivas alternativas - "heterotopias", "entre-lugar", "espaço fronteiriço", "não-lugar", "espaço virtual" - outra, aponta para o desaparecimento da exterioridade. Neste trabalho proponho discutir a relação entre o lugar e a identidade, tomando como base a figura histórica do indio yamana Orundellico, mais conhecido pelo nome de Jemmy Button que, em 1830, foi levado para a Inglaterra e retornou para a Terra do Fogo, após três anos. Seleciono, ao final, exemplos de intelectuais contemporâneos que pertencem a duas culturas e comento o fenômeno da "dupla consciência". Palavras-chave: lugar; identidade; Jemmy Button; Terra do Fogo; Inglaterra.

\begin{abstract}
The opposition between "inside" and "outside" that for a long time guided our image of space now faces renewed territorial challenges. While one branch of contemporary thought regarding space highlights the importance of alternative perspectives such as "heterotopias", "in-between place", "bordering space", "non-place", "virtual space", another branch points to the disappearance of the exteriority. This paper aims to discuss the relation between place and identity focusing on the historical figure of Orundellico, better known as Jemmy Button, a yamana Indian that was taken to England in 1830 and returned to Tierra del Fuego three years later. At the end, I select examples of contemporary intellectuals that belong to two different cultures in order to examine the idea of "double consciousness".

Keywords: place; identity; Jemmy Button; Tierra del Fuego; England.
\end{abstract}

